MEDICOLEGAL

\title{
Consent to treatment: the medical standard reaffirmed
}

\author{
BY OUR LEGAL CORRESPONDENT
}

At last a case concerning consent to medical treatment has reached the Court of Appeal, and the result has been a resounding rejection of American and Canadian developments in the law of informed consent-with a correspondingly firm approval of the medical standard which has long been accepted in Britain.

In English law a patient has two ways of claiming against a doctor who is said to have failed to obtain proper consent for treatment. One is to sue in battery (more often known, though not strictly accurately, as assault): cutting a patient with a scalpel is undoubtedly a battery if the patient has not consented to be cut. This route has the advantage for the plaintiff that he is not required to go on to prove that the absence of consent was in any way material-that is, that if the operation had been fully explained to him he would not have consented to it.

Alternatively the patient may claim negligence, alleging that the doctor failed in his duty to give a sufficiently full explanation of the risks inherent in the proposed procedure. "Because of that breach of duty," says the patient, "I agreed to the operation; the operation went wrong-through nobody's fault-and now I have suffered extensive personal injury."

If the claim is in negligence the patient must show that the negligence was linked with the injury. In other words, he must prove that had the duty to inform been complied with he would have declined the operation.

\section{Actions in battery}

No doubt because of the lack of requirement for a causative link to be shown judges have recently taken to expressing their strong disapproval of the battery action. They have, furthermore, given practical force to their views by requiring a rather greater failure of communication in cases of battery than in claims for negligence before they will find that consent was vitiated. In the words of Mr Justice Bristow, "once the patient is informed in broad terms of the nature of the procedure which is intended, and gives her consent, that consent is real, and the cause of action on which to base a claim for failure to go into risks and implications is negligence, not battery."1

The origin of this legal principle can be traced to 1957, when such actions were still tried by a jury. A patient alleged that his doctor had failed to warn of the risks inherent in electroconvulsive therapy. The judge directed the jury that the doctor had done enough if he had acted in accordance with a practice accepted as proper by a responsible body of men skilled in that particular art. ${ }^{2}$

This case was followed by other decisions of judges of first instance and was specifically approved by the House of Lords in two cases which, being concerned with claims of negligent treatment (Whitchouse $v$ fordan) and diagnosis (Maynard $v$ West Midlands Regional Health Authority), were not directly auth- oritative on the slightly different question of negligent advice. ${ }^{3}$

\section{Medical standard}

What has emerged from the case law is the so called "medical standard." British law requires the doctor to supply the patient with sufficient information to enable him to decide whether or not to undergo his operation, but the standard of sufficiency is that which is rightly accepted as proper by a body of skilled and experienced medical men.

Broadly speaking, two differences may be seen between the law in British jurisdictions and the rules which are developing in Canada and the United States. The transatlantic doctrine requires a much more detailed disclosure of possible risk, and the standard used is not the medical standard but standard determined by the court with the assistance of medical and other evidence. This point is illustrated by the recent words of the Chief Justice of Canada: "The materiality of non-disclosure of certain risks to an informed decision is a matter for the trier of fact [the judge], a matter on which there would, in all likelihood, be medical evidence but also other evidence, including evidence from the patient or from members of his family."4 In other words, expert medical evidence would be admissible but would not determine the matter: good medical practice would simply be one factor for the judge to consider.

The British doctrine has been accused of abdicating the power of decision to the doctors. That is hardly a fair criticism, for the court in fact retains a central role. As Mr Justice Hirst put it in Hills $v$ Potter, "In every case the court must be satisfied that the standard contended for on [the doctors'] behalf accords with that upheld by a substantial body of medical opinion, and that this body of medical opinion is both respectable and responsible, and experienced in this particular field of medicine."

\section{Appeal case}

The case which has now been decided by the Court of Appeal is Sidaway $v$ Board of Governors of Bethlem Royal Hospital. ${ }^{5}$ Mrs Sidaway claimed damages for negligence by a neurosurgeon on the grounds of his failure to disclose or explain to her the risks inherent in the operative procedures he advised. The patient had suffered pain in her neck and right shoulder and was referred to a neurosurgeon at the Maudsley Hospital, who correctly diagnosed a narrowing of the spinal column between the fifth and sixth vertebrae. A first operation in 1960 was successful. After 13 years the pain returned. A second operation took place in 1974. This was a laminectomy of the fourth cervical vertebra and a facetectomy or foraminectomy of the disc space between the fourth and fifth cervical vertebrae. The operation carried an inherent risk of damage to the spinal cord, regardless of the skill and care of the surgeon. That risk was assessed as a $1 \%$ to $2 \%$ risk of ill effects ranging from the mild to the catastrophic.

The surgeon did not tell Mrs Sidaway that the operation was elective, and though he referred to the possibility of disturbing a nerve root he did not mention the risk of damage to the spinal cord. But in doing so he was following a practice which would, the judge found, have been accepted in 1974 as proper by a responsible body of skilled neurosurgeons. In the event, damage did occur to the spinal cord and Mrs Sidaway was left with a severe disability. She claimed that if the surgeon had complied with what she said was his duty-namely, to disclose to her the inherent specific risks of the procedureshe would not have consented to undergo the operation.

\section{Full disclosure}

In the course of argument Mrs Sidaway's counsel claimed that the patient has a right to full disclosure of all real risks inherent in any proposed operation, that this right is an absolute one, and that it is for the court, not a consensus of medical men, to decide the extent of disclosure required. He relied on the American and Canadian cases which support this proposition. The trial judge, Mr Justice Skinner, found a clear divergence in principle between the English decisions and the transatlantic cases, and felt boundthough he was hardly reluctant - to follow the former. He put the English doctrine in this way: "A doctor has a duty to use reasonable care and skill in all his dealings with his patients and the patients have no more, and no less, than the concomitant right. The duty is fulfilled if the doctor acts in accordance with a practice accepted as proper by a body of skilled and experienced medical men."

Dismissing Mrs Sidaway's appeal, the Court of Appeal has slightly elaborated that statement of principle in a way which reasserts the judge's right to satisfy himself that the body of medical opinion supporting the medical standard is itself (in $\mathrm{Mr}$ Justice Hirst's words) respectable, responsible, and experienced.

The elaboration proposed by Sir John Donaldson, the Master of the Rolls, and accepted by his colleagues, was to add the word "rightly" to the trial judge's formulation. "The duty is fulfilled," he said, "if the doctor acts in accordance with a practice rightly accepted as proper by a body of skilled and experienced medical men."

\section{Professional judgment}

He emphasised that there was a duty to give sufficient information to enable a patient to reach a rational decision. The nature and extent of the information and the manner and timing of its disclosure were very much matters for professional judgment in the context of the doctor's particular relationship with the particular patient. The general duty of the doctor was to take such action by way of giving or withholding information as was reasonable in all the circumstances of which the doctor knew or ought to have known, including the patient's true wishes, with a view to placing the patient in a position to 
make a rational choice whether or not to accept the doctor's advice.

Sir John also emphasised, however, that the medical standard was not in the last analysis a matter for the doctors: it was a matter for the law, and the courts would not sit idly by if the medical profession, "by an excess of paternalism," denied their patients a free choice. The law would not allow the medical profession to play god.

The report of the judgment of Lord Justice Dunn, who agreed with the Master of the Rolls, shows a slightly different emphasis. $\mathrm{He}$ stated that the American doctrine of "informed consent" formed no part of British law. A contrary result would be damaging to the relation of trust and confidence between doctor and patient and might have an adverse effect on the practice of medicine. He doubted that the American doctrine would offer any majo benefit to patients, most of whom preferred to put themselves unreservedly in the hands of their doctors. That was not paternalism but simply an acceptance of the doctor-patient relationship as it had developed in Britain. $\mathrm{He}$ advanced a policy consideration: the chief effect of accepting the argument advanced for Mrs Sidaway - that the patient has an absolute right to full disclosure of all real risks inherent in an operation-would be likely to increase the number of claims against doctors for professional negligence. That would be likely to have an adverse effect on the general standard of medical care, for doctors would be more concerned to safeguard themselves than to concentrate on their primary duty of treating their patients.

Mrs Sidaway was given leave to appeal to the House of Lords. In view of the approval which the House of Lords has recently given in the cases of Whitehouse and Maynard to the line of authority traced and followed by the Court of Appeal, her appeal seems unlikely to succeed.

\section{References}

${ }^{1}$ Chatterton $v$ Gerson. [1981] 1 QB 432, per Bristow J. The judge actually used the word "trespass," not "battery": battery is a species of trespass. See also Hills $v$ Potter, The Times, 23 May 1983, per Hirst J. I grossly traduced Mr Justice Hirst's decision in a piece entitled "The Limits of Consent," Br Med $\mathcal{F} 1983$; 286:1982. A very compressed Times law report stated erroneously that Mrs Hills's claim was brought in battery alone while the judge based his decision, apparently, on the principles appropriate to a claim in negligence: over-hasty criticism followed in these columns. A full transcript of an unimpeachable judgment reveals that the claim was actually brought in both battery and negligence.

${ }^{2}$ Bolam v Friern Hospital Management Committee [1957] 2 All ER 118

${ }^{3}$ Whitehouse $v$. fordan [1981] 1 All ER 267. Maynard $v$ West Midlands Regional Health Authority, The Times 1983 May 9:20.

Reibl v Hughes (1980) 114 DLR (3d) 1.

5 The Times 1984 February 24:24.

\section{MEDICAL NEWS}

\section{Cancer trials register}

The UK Cancer Trials Register of the Committee on Cancer Research has registered over 200 trials since it was set up in 1981. The register provides an easily accessible source of information for clinicians who wish to enter patients into trials. The steering committee has recently decided to extend the scope of the register to include details of all current phase I, phase II, and phase III cancer treatment trials, providing that the trials are carried out prospectively along the lines of a specific protocol. All those who would like their trials to be included in the register are invited to complete a trials registration questionnaire. Details of

\section{COMING EVENTS}

Association of Medical Advisers in the Pharmaceutical Industry-Symposium "Medicine, the pharmaceutical industry, and sport," 28 March, London. 20 Queensberry Place, London SW7 2DZ. (Tel 01589 9067.)

Royal Society-Meeting for discussion "Aspects of gene expression and its control," 29-30 March. London. Details from the executive secretary of the society, Carlton House Terrace, London SW1Y 5AG,

British Academy of Forensic Sciences-25th annual scientific meeting "Medicine, science, sport, and the law," 4 April, London. Details from the secretary general of the academy, department of forensic medicine, London E1 2AD. (Tel 01377 9201.)

British Medical Association Midland Regional Office-Seminar "Employment law: the hidden cost," 3 April, Coventry. Details from the BMA office, 36 Harborne Road, Birmingham B15 3AJ. (Te
2561.) Closing date for applications 19 March.

Society for Drug Research-Symposium "The role of membrane receptors in drug discovery," 5 April, London. Details from the society, c/o Institu
Biology, 20 Queensberry Place, London SW7 2DZ.

\section{SOCIETIES AND LECTURES}

For attending lectures marked * a fee is charged or a ticke is required. Applications should be made first to the institutions concerned.

\section{Monday 12 March}

Royal College of Surgeons of ENGLand-5 15 pm, Hunterian lecture by Professor C Chilton: The and pelvic floor musculature of the male and female and their relationship to urinary incontinence. ( $\operatorname{Pr}$ ceded by tea $445 \mathrm{pm}$. Followed by buffet supper. St GEORGE's Hospital. MEDICAL SCHOOL-1230 pm, registered trials and copies of the questionnaire are available from Miss G E Chrusciel, UK Cancer Trials Register, Medical Research Centre, 20 Park Crescent, London W1N 4AL, tel 016365422 ext 327.

\section{Kidney transplants}

The number of kidney transplants undertaken in the United Kingdom and the Republic of Ireland for the four weeks ending 20 February was 103, and the number of potential recipients on file was 2707 . Corresponding figures for the previous four weeks ending 23 January were 74 and 2717 . obstetrics and gynaecology departmental post
graduate lecture by $\mathrm{Mr}$ Anthony Firth: How do graduate lecture by $\mathrm{Mr}$ Anth

molecules cross the placenta ? 530 pm Freud memorial lecture in psychoanalysis by Professor A Solnit: Preparing and remembering: contributions to a psychoanalytic view of human development. IV reflections.

Tuesday 13 March

UNIVERSITY OF CAMBRIDGE-At Department of Histor and Philosophy of Science, $5 \mathrm{pm}$, Dr Andrew Wear: Puritan and Anglican perceptions of illness in the seventeenth century.

\section{Wednesday 14 March}

Clinical Research Centre-4 30 pm, Professor M G Gelder: Anxiety disorders: new approaches to old problems.

作 rowska: Uses of immunofluorescence.

worth: Knock knees. 7 pm, Professor L Kessel: Tibia vara.

ROYAL. COLlEge OF SURGEONS OF EDINBURGH-3 $30 \mathrm{pm}$, William Guy memorial lecture by Professor J P Moss: Bones, muscles, and malformation. An investigation into craniofacial abnormalities. RoYAL College of SuRGEONS OF ENGLAND-5 pm,
Hunterian lecture by Professor C J Cahill: Oral bile salts in the prevention of renal failure in patients with obstructive jaundice.

RoYal Free Hospital SCHOOL OF Medicine- 5 pm guest lecture by

Royal Masonic Hospital-7 pm, Dr D N Croft: OYAL MASONIC HOSPITAL-7 pm, Dr D N Crof : $630 \mathrm{pm}$ )

Royal Postgraduate Medical School-Stamp Lecture Theatre, $1015 \mathrm{am}$, medical staff round

WILLESDEN HOSPITAL MEDICAL SOCIETY-8 $30 \mathrm{pm}$, D A Ghosh: Phobic disorders.

Thursday 15 March

UNIVERSITY OF CAMBRIDGE-At department of pathology, $430 \mathrm{pm}$, Professor D L Gardner: Low temperature electron microscopic techniques in the investigation of human and animal osteoarthrosis.
Saturday 17 March

NuFfield DEPARTMENT OF ORTHOPAEDIC SURGery, OXFORD-9 $30 \mathrm{am}$, Dr P Davies: Sociological aspects of orthopaedic practice.

\section{BMA NOTICES}

\section{Central meetings}

MARCH

13 Tues Hospital Junior Staff Committee, $10 \mathrm{am}$.

15 Thurs General Medical Services Committee, 10

28 Wed Negotiating subcommittee (CCHMS), 10

29 Thurs General purposes subcommittee (CCHMS), $10 \mathrm{am}$.

\section{Division meetings}

Members preposing to attend meetings marked * are asked to notify in advance the honorary secretary concerned.

Aldershot and Farnham-At Cambridge Military Hospital, Thursday 15 March, $615 \mathrm{pm}$, spring clinical meeting.

Bromley-At Farnborough Hospital, Friday 16 March, $8 \mathrm{pm}$, wine tasting.

Cambridge, Huntingdon, and Ely-At New Addenbrooke's Hospital, Wednesday'14 March, 7 pm agm and lecture by Dr A N B Stott: "The implication or health of radioactive waste disposal."* (Supper provided.)

East Yorkshire-At Penny Arcadia, Ritz Cinema, machines. 15 March, visit to collection of gambling Glasgow and West of Scotland-At Glasgow Regional Office, Saturday 17 March, 730 for $8 \mathrm{pm}$, photographic competition *

Halifax-At Halifax General Hospital, Thursday 15 March, $8 \mathrm{pm}$, informal social/discussion meeting, guest Dr Andrew Vallance-Owen and Brian Richardson from BMA Leeds Office.* (Refreshments provided.) At 8 pm, annual dinner dance.* (Guests invited.) Lanarkshire-At Bellshill Hospital, Wednesday 14 March, 8 pm, annual BMA lecture by Mr J Ross Harper:
"Medicine and the law."* (Members of Glasgow
Division invited.*)

Mid Glamorgan-At East Glamorgan Hospital, Thursday 15 March, 730 for $8 \mathrm{pm}$, combined meetin with Rhondda Medical Society, speaker Professor G Mitchell: "Drugs of addiction."

Rugby-At St Cross Hospital, Thursday, 1230 for pm, agm.* (Snack lunch available.*)

Wakefield and Pontefract-At Swallow Hotel, Wakefield, Thursday 15 March, 730 for $8 \mathrm{pm}$, lecture
dinner, speaker Mr Eric Houlder: "History in loo." Guests invited.)

Waltham Forest-At Chasneys of Chingford, Thursday 15 March, 730 for $8 \mathrm{pm}$, annual dinner speaker Sir John Ellis.* (Guests invited.)

West Sussex-At Avisford Park Hotel, Tuesday 13 March, 730 for 8 pm, dinner meeting.* Wigtown-At Judge's Keep Hotel, Friday 16 March,
730 for 8 pm, Dr Robin Hardie: "Treatment of skin diseases.'

() British Medical Journal 1984

All Rights Reserved. No part of this publication may be reproduced, stored in a retrieval system, or transmitted, in any form or by any means, electronic, mechanical, photocopying, recording or otherwise, without the prio
permission, in writing, of the British Medical fournal. 